\title{
THE COMBINED APPROACH TO SOLVING ISSUES OF THE FLOOD HAZARD ASSESSMENT USING WATER GAUGE RECORDS AND SPATIAL DATA
}

\author{
Vasyl Korbutiak ${ }^{凶}$, Dmytro Stefanyshyn, Oleh Lahodniuk, Alina Lahodniuk
}

National University of Water and Environmental Engineering, Rivne

\begin{abstract}
The research deals with the combined approach to boost the reliability of hydrological estimates based on a series of observations being supported by spatial data. In particular, the application of various theoretical curves of probability distribution or situations that may occur at submountain sections of rivers (for example, alluvium accumulation or river bed erosion) is considered. Because of the obsolete cadastral data on the riverbeds and catchments, the necessity of the use of remote sensing is substantiated. Assessment of the dynamics of changes in the river cross-section profiles allows making conclusions concerning the direction of the channel deformations - deepening and straitening the river channels or increasing their cross dimensions. This information may complement the assessment of flood protection of the territories.
\end{abstract}

Key words: water discharges, channel transformations, anthropogenic impact, hydrological data

\section{INTRODUCTION}

Rivers are the main source of drinking, industrial and agrarian water supply, serve as transport routes and provide energy resources, and also are very important for the development of the tourism and recreation industry. That is why, historically, human settlements were formed around water objects. Subsequently, the proximity of man to the water led to the development of channel and coastal infrastructure and, accordingly, caused the need to estimate the amount of water, sediment, dissolved elements in different phases of the river regime for the safe use of coastal areas and water resources.

Extreme hydrological regimes, namely low flow and floods, are of particular importance. Floods are among the most dangerous natural disasters causing human fa- talities and different losses (Abbott, 1999). According to estimates (Doocy, Daniels, Murray \& Kirsch, 2013), floods were responsible for about 6.8 million deaths in the 20th century. Annual economic worldwide losses from floods reached hundreds of millions of dollars (Dobrovičová, Dobrovič \& Dobrovič, 2015), and the risk of deaths and catastrophic losses due to floods has been increasing year-by-year, in particular through the accelerated urbanization of coastal areas, river basins and lakeshores, despite people fearing floods (Rufat, Tate, Burton, Maroof \& Say, 2015). The reasons, phenomena, factors and events that precipitate in floods are diverse, multifaceted, and interrelated (Viessman, Harbaugh \& Knapp, 1975; Doocy et al., 2013). These include weather factors such as storms, heavy or sustained rainfalls, rapid snow melts, heavy rains combining with rapid snowmelts, etc. Typical human

Vasyl Korbutiak https://orcid.org/0000-0002-8273-2306; Dmytro Stefanyshyn https://orcid.org/0000-0002-7620-1613; Oleh Lahodniuk https://orcid.org/0000-0001-6830-3700; Alina Lahodniuk https://orcid.org/0000-0001-8561-7410

$\otimes_{\text {v.m.korbutiak@nuwm.edu.ua }}$ 
Korbutiak, V., Stefanyshyn, D., Lahodniuk, O., Lahodniuk, A. (2020). The combined approach to solving issues of the flood hazard assessment using water gauge records and spatial data. Acta Sci. Pol. Architectura, 19 (1), 111-118. doi: 10.22630/ASPA.2020.19.1.12

factors include breakthroughs of dams, spreading water-impervious surfaces in human settlements, defects or failures of drainage systems, etc. Deforestation (Raven \& Berg, 2006), physical land features, including the phase state of soils of the underlying surface, the present or absence of vegetation, other river basin drainage characteristics, also influence flood outcomes. Climate changes and the overall environment degradation must also be mentioned (Viessman et al., 1975; Briggs, Smithson, Addison \& Atkinson, 1997; Raven \& Berg, 2006; Doocy et al., 2013).

In Ukraine, flood challenges are also relevant (Susidko \& Lukianets', 2004). Floods occur particularly often on the Carpathian rivers in the western regions of our country (Kyryliuk, 2001; Susidko \& Lukianets', 2004; Boiko \& Petrenko, 2006). Floods also threaten the population living in the Dnieper river basin. First of all, floods pose a significant threat to the population living in the Pripyat river basin (Susidko, 2006). There is also a permanent danger of artificial floods due to accidents on numerous dams (Stefanyshyn, 2011).

Therefore, forecasting risks of floods in our country is one of the important problems, and its relevance will even be increasing over time. In addition, in recent times in the country, problems of low runoff have also been actualized bringing about additional water risks. The attraction of large volumes of water into economic circulation, water pollution and irreversible water losses, the large-scale transformation of riverside landscapes and catchment areas after hydraulic construction and reclamation, have disturbed the natural balance of most river ecosystems, leading to the depletion of water resources in many regions of the state.

As it is known, in modern hydrology, there are two principal approaches to the study of hydrological characteristics. They can be conventionally defined as probabilistic (or statistical) approach and genetic (deterministic) one. The genetic approach is the most adequate and scientifically correct but very complicated to be practiced because hydrological phenomena and processes in the overwhelming majority are multifactorial, interrelated and random. Therefore, nowadays, various probabilistic methods are more popular in practical calculations of hydrological characteristics, especially extreme ones (maximal and minimal), and the probabilistic approach to hydrological research is typical of most countries of the world, where long-term hydrological observations are conducted (Viessman et al., 1975).

The basis of the probabilistic approach to forecasting hydrological characteristics (water levels, discharges, volumes of water, etc.) is the use of methods of mathematical statistics and probability theory while processing data of hydrometric and hydrologic observations on water gauge stations. The basic mathematical model used to forecast these characteristics is the probability distribution function (Viessman et al., 1975; Kritskyi \& Menkel', 1981; van Gelder, Wang \& Vrijling, 2006; Koutsoyiannis, 2008). It can be used to determine flood and low flow parameters and its occurrence probability, to estimate the probable losses (risks of losses) because of floods and water shortages, to solve water management problems, to assess the design values of water levels and discharges having extreme exceedance probability in designing hydraulic structures etc. (Stefanyshyna-Havryliuk, Stefanyshyn $\&$ Trofimchuk, 2014; Stefanyshyn, 2015). The use of probability distributions in hydrology is based on the assumption that hydrological observation data form representative sequences of independent and identically distributed random variables (Viessman et al., 1975; Kritskyi \& Menkel', 1981; Vasiliev et al., 2007; Koutsoyiannis, 2008). For most rivers that have not undergone significant anthropogenic loads, and in the presence of data of continuous hydrological observations within time intervals of at least $30-40$ years, this assumption can be quite admitted (Viessman et al., 1975; Kritskyi \& Menkel', 1981).

\section{MATERIAL AND METHODS}

It was considered an example of the discrepancy (uncertainty) of long-term forecasts of maximum flood water discharges based on extrapolations using various probability distribution functions.

To do this, we looked up a case of the forecasting water discharges maxima for the Dnieper river, the Vyshgorod water level gauge, due to a number of observations from 1787 to 1999 (Fig. 1) with the following statistical parameters: the mean value $\bar{x}=$ $4,692 \mathrm{~m}^{3} \cdot \mathrm{s}^{-1}$; the standard deviation $\sigma=2,632 \mathrm{~m}^{3} \cdot \mathrm{s}^{-1}$; 


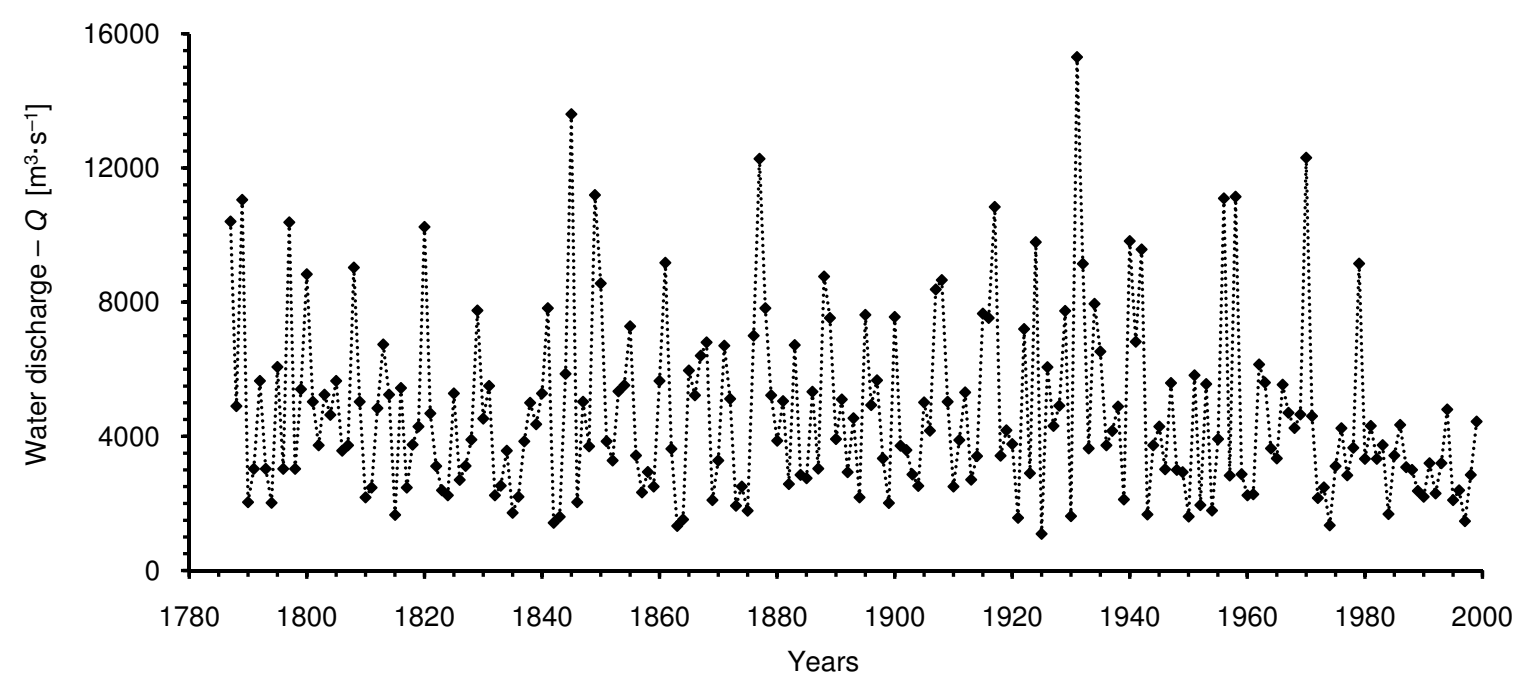

Fig. 1. A time series of water discharges maxima, the Dnieper river, the Vyshgorod water level gauge (own elaboration)

the coefficient of variation $C_{v}=0.56$; the coefficient of asymmetry $C_{s}=1.26$.

The undeniable importance of remote sensing systems as an instrumental monitoring segment is evidenced, for example, by the significant transformation in river systems caused by human activities. An example of such transformation can be the situation occurred on the Stryi river between the villages Khodovychi and Pischany (49.294099 N, 23.944477 E) - Figure 2. In our researchers we use data of in-situ measurement (Kaftan \& Korbutiak, 2001) on that section.
By 1985, several quarries had been operated above and below this site, their total capacity used to amount to 4.5 million $\mathrm{m}^{3}$ annually. The natural inflow of the river sediment to the section is estimated at about $30,000 \mathrm{~m}^{3}$ annually. During the functioning of quarries (from 1971 to 1985), the water levels in the river decreased by $4 \mathrm{~m}$ (Figs. 2, 4). Violation of the previously established natural dynamic balance led to a change in the type of the river fluvial-morphological process. The braided type of the river fluvial-morphological process has changed to the meandering one. It caused a number

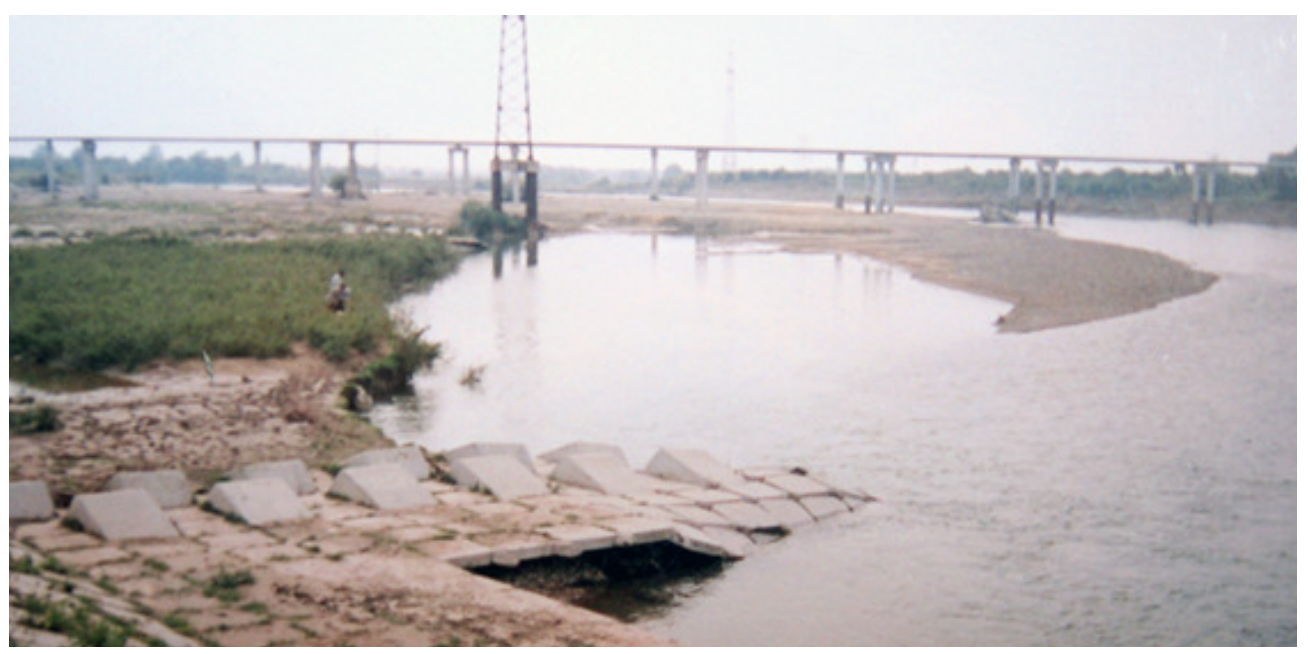

Fig. 2. Stryi river between the villages Khodovychi and Pischany (own photo, 2000) 
of ecological and economic problems. In particular, in the 1970s, six underground and two aboveground lines of gas transmissions were disrupted, and the huge flooding of 1980 destroyed the highway bridge of the Lviv-Ivano-Frankivsk-Chernivtsi road, as well as the bridge of the Lviv-Khodoriv railway line.

\section{RESULTS}

The presence of a long series of observations does not guarantee a reliable definition of the estimated water discharges or levels. In general, this applies to any prediction based on extrapolation models, including probability distribution functions, because the complete matching of analytic functions (taken as such models) with empirical data cannot be at all. By the law of random variations, the frequency distribution in the samples of observation series will always differ from the theoretical probabilities (Tikhonov, Honcharskyi, Stepanov \& Yagola, 1983; Rozhdestvenskyi, Ezhov \& Sakhariuk, 1990; Jerina, 2001).

Eight alternative probability distributions were used to forecast (Fig. 3), including four variants of the three-parameter gamma distribution according to the Krytsky-Menkel model: model 1 corresponds $C_{v}=0.5$ and $C_{v}=2 C_{s}$; model 2 answers $C_{v}=0.5$ and $C_{v}=2.5 C_{s}$; model 5 satisfies $C_{v}=0.6$ and $C_{v}=2 C_{s}$; model 6 stands for $C_{v}=0.6$ and $C_{v}=2.5 C_{s}$.

The other distributions are as follows: model 3 answers the Pearson 3rd type distribution (arithmetical); model 4 stands for the 1st type Gumbel distribution; model 7 satisfies the two-parameter lognormal distribution; model 8 corresponds the log-Pearson 3rd type distribution. This requires taking risks into account when making a decision on an appropriate model of probability distribution. But the main problem that is unsolvable in the framework of the statistical approach remains. This problem is the fundamental inability to carry out the forecasting of every subsequent extreme hydrological phenomenon, for example, the parameters of the next flood.

As is shown in Figure 3, depending on distribution law, the same annual exceedance probability of $0.1 \%$ (design value for Kyiv hydroelectric complex) corresponds to different values of water discharge maxima. And, accordingly, the design value of water discharge maxima suits a different exceedance probability. Furthermore, all that analytical probability distribution laws were checked by statistical hypotheses based on the Pearson criterion for the significance level of $0.1 \%$ and it is determined that they may consider as hypotheses, which agree with empirical data. So, the selection of the distribution curve should correspond with different hydromorphological data about the channel condition and drainage area both actual and historical. The role of satellite surveying could be especially important to get the relevant data.

The mountain and sub-mountain river areas have their own peculiarities. At first, there is an insufficient number of gauge stations in these areas. This is due to the fact that the gauge stations are usually arranged on relatively straight and stable sections of the rivers, and

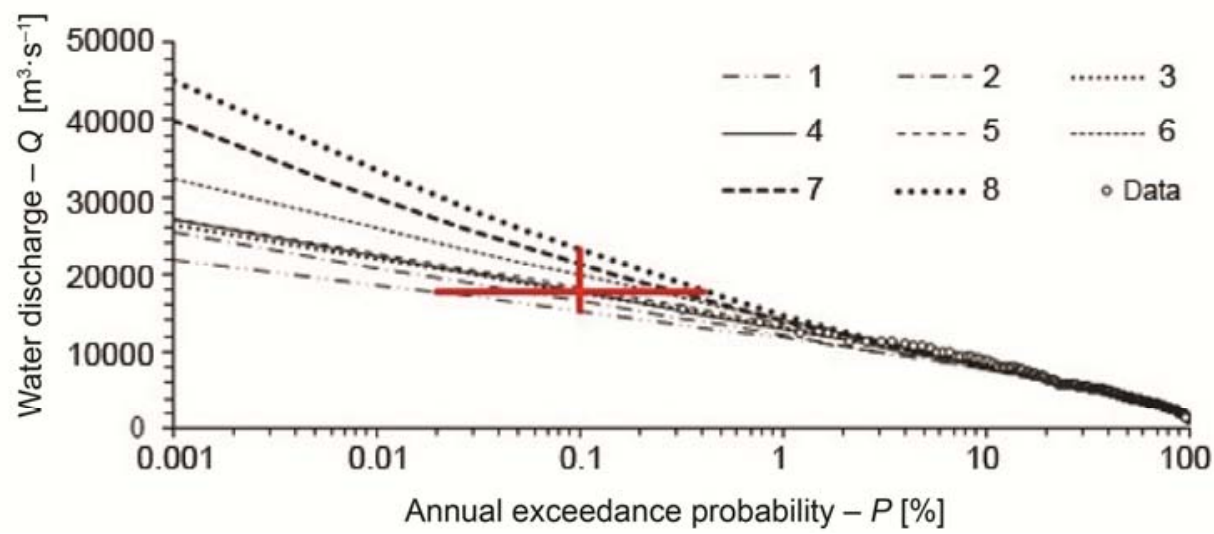

Fig. 3. The probability distributions of water discharges maxima, the Dnieper river, the Vyshgorod water level gauge (own elaboration) 
foothill areas are characterized by intense planar and high-altitude deformations. Secondly, there is some distorted homogeneity of the series of observations or their insufficient duration. It may be a consequence of significant human-induced interference with river systems and the frequent destruction of gauge stations during floods. Thirdly, it is very difficult, often impossible, to perform hydrometric works during flood events. And, as a rule, there are no reliable hydrometric data concerning floods for management and design works. Therefore, hydraulic facilities on the rivers are often calculated using regional-specific formulas. These are reduction formulas, runoff volume formulas, formulas of limiting intensity and genetic formulas, where one of the key parameters is the lag time. Sometimes, it crucially sets out the hydraulic and morphological features of the rivers. Modern software complexes allow automating the appropriate calculations.

It should be noted that the calibration of the river runoff models requires detailed information about the spatial characteristics of the formation of the runoff. Consequently, the common feature of both approaches is the need to take into account the current state of river catchments.

In-situ observations allowed obtaining a series of the river channel's cross-section shapes, such as Figure 4. There were fixed both the period the river channel's entrenchment, and the beginning of the restoration of its historical altitudes (Kaftan, 1975; Korbutiak, 2000).
The analysis of the observation results allows us to trace that the entrenchment processes for the submountain rivers are accompanied by a significant increase of the river's channel volume (Kaftan \& Korbutiak, 2001). On the other hand, the process of channel restoration and its structural sediment forms starts with decreasing the channel volume and raising the floodplain altitudes. Consequently, the tendency to changes of the floodplain part indicates a lack of stability of the river fluvial-morphological processes, and, accordingly, indicates the need to take into account changes of the slopes and hydromorphological conditions of the water flow and transportation of sediment both for maximum and minimum hydrological regimes. The revealed features enhance frames of using Earth remote sensing data to observe rivers in the mountain and sub-mountain areas. In particular, it refers to open radar data (SRTM, Aster, Sentinel), for which the resolution is commensurate with the width of the channels of medium-sized rivers, and therefore they often cannot be used for direct monitoring of the altitude dynamics of the river's structural sediment forms.

On the other hand, situations with a significant accumulation of alluvium material on the rivers are also widespread (Fig. 5). This may be due to the operation of hydraulic structures, the growth of erosion on the catchment areas (deforestation, agriculture activity). All these examples show the impossibility

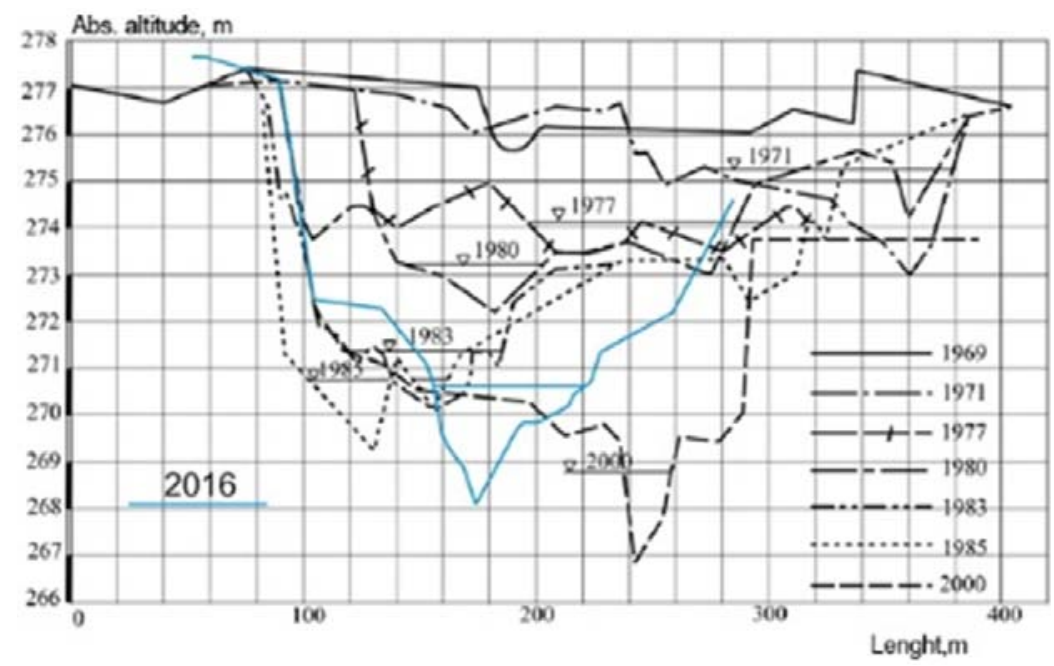

Fig. 4. Channel transformations of the Stryi river between the villages Khodovychi and Pischany (own elaboration) 


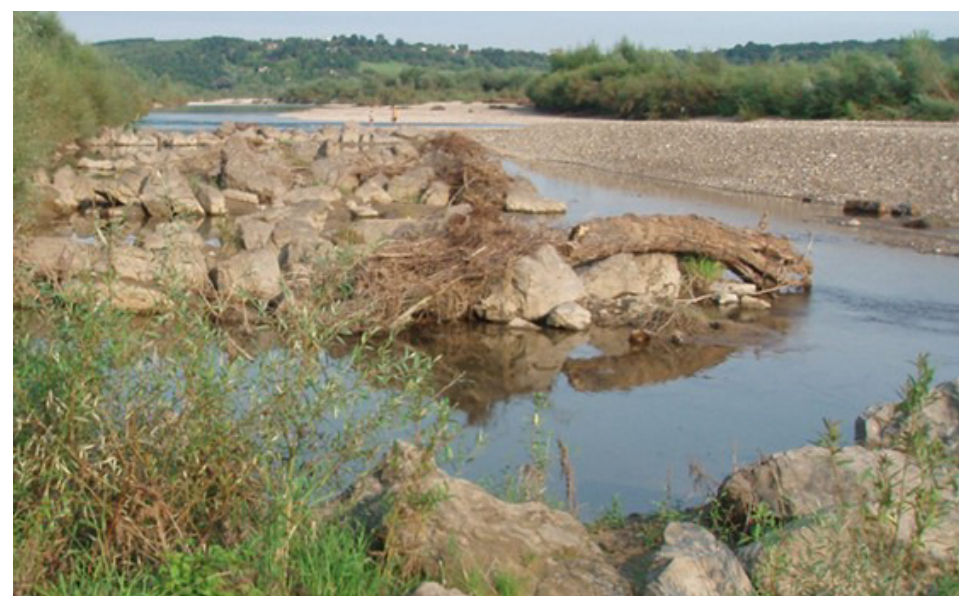

Fig. 5. A fragment the deposition of sediment within the sub-mountain river section - Limnytsia River near Temerivtsi (own photo)

of creating reliable models of river systems without actual spatial data.

\section{DISCUSSION}

Nowadays, changes in rivers and catchment areas have reached so significant levels that reliable data on runoff may only be obtained by using constant spatial monitoring. As it is shown that even in the presence of a large scale of observations while solving of runoff estimation tasks lots of uncertainty still remains, which may be overcome owing to actual spatial data. Sharp changes of hydromorphological conditions often cause the development of active channel deformations (Korbutiak, Korbutiak \& Kaftan, 2013). For forecasting of appearing dangerous erosion in local zones of the river channel, an approach to solve the relevant intellectual task was developed (Stefanyshyn, Korbutiak \& Schodro, 2010; Khodnevych, Stefanyshyn \& Korbutiak, 2017). Mathematical modelling of kinematic flow characteristics is realized within the framework of a three-dimensional model using Reynolds' equations. Computer simulation based on using a synthesis of the results of spatial analysis, morphological, hydrological and hydraulic investigations and numerical mathematical modelling of the kinematics of turbulent flows showed acceptable results close to situations observed in reality.

It should be noted that in case of solving these forecast tasks, the mathematical modelling of the kinematic characteristics of local turbulent flows needs to be pro- vided with actual geospatial data. It helps detect potentially dangerous river sections with a high level of risk of intensification of local erosion. In particular, it enables the conditions of intensification of local river erosion to set out depending on the main river hydromorphological characteristics and types of fluvial-morphological process (incomplete, limited, free meandering, focal type) occurring on a majority of domestic rivers.

The adequate interpretation of monitoring data, calculation results and spatial modelling using index images may be achieved owing to the synthesis of knowledge from various natural and informational disciplines. Obviously, tasks of estimating the river runoff characteristics are complex intellectual issues, where remote sensing may be set out as one of a crucial task.

The results of the processing of Earth remote sensing data help to solve the task of the calibration of the river runoff models effectively. Remote sensing systems boost monitoring systems. They are reliable sources of basic spatial data for hydrological software systems providing cadastral data that may be used in calculations by regional-specific formulas or using a series of long-term observations.

\section{CONCLUSIONS}

Different analytic functions (probability distributions, trends) considered as working hypotheses in the choice of approximating extrapolation models in many cases give similar results within the observed 
data, while the prolongation of the forecasting intervals beyond the available empirical data leads to an increase of differences between models. While evaluating the runoff, one must take into account a lot of different factors that affect it. First of all, the significant anthropogenic transformation of river basins bringing about changes in the structure of vegetation cover, hydrographic network, river channels, and water balance too, must be mentioned. The adequacy and reliability of the river runoff models are also affected by the heterogeneity of the observation series, which is inherent in a large number of gauge stations. Obviously, the perspective for creating reliable runoff forecast models depends crucially on using appropriate generalizing geographic parameters, which can holistically characterize the conditions of the runoff formation. Among them, such parameters should be mentioned as the ability of the catchment to precipitation retention, water yield, the roughness of the channel and floodplain, the linear dimensions of the sediment structural forms, the granulometric composition of river sediment, type of channel process, channelforming water discharge. All these parameters can be set out due to using remote sensing data. In this case, parameter relationships obtained by in-situ measurements can be useful. As an unresolved problem, the assessment quality of the capacity of river catchments to precipitation retention and water yield from the drainage area should be boosted.

\section{REFERENCES}

Abbott, P. L. (1999). Natural disasters. 2nd ed. Boston: WCB/McGraw-Hill.

Boiko, V. M. \& Petrenko, L. V. (2006). Stykhiyni hidrolohichni yavyshcha na richkakh Ukrayiny $v$ ostanni 10-15 rokiv ta problemy yikhn'oho operatyvnoho poperedzhennya [Natural hydrological phenomena on the rivers of Ukraine in the last 10-15 years and the problems of their operational prevention]. Naukovi praci UkrNDHMI, $255,272-278$.

Briggs, D., Smithson, P., Addison, K. \& Atkinson, K. (1997). Fundamentals of the physical environment. 2nd ed. London: Routledge.

Dobrovičová, S., Dobrovič, R. \& Dobrovič, J. (2015). The economic impact of floods and their importance in different regions of the world with emphasis on Europe. Procedia Economics and Finance, 34, 649-655.
Doocy, S., Daniels, A., Murray, S. \& Kirsch, T. D. (2013). The human impact of floods: a historical review of events 1980-2009 and systematic literature review. PLOS Currents Disasters, 16 April. 1st ed. doi: 10.1371/currents. dis.f4deb457904936b07c09daa98ee8171a

Gelder, P. van, Wang, W. \& Vrijling, J.K. (2006). Statistical estimation methods for extreme hydrological events. In O. Vasiliev, P. van Gelder, E. Plate \& M. Bolgov (Eds.) Extreme Hydrological Events: New Concepts for Security. NATO Science Series. Vol. 78 (pp. 199-252). Dordrecht: Springer. doi: 10.1007/978-1-4020-5741-0 15

Jerina, A. M. (2001). Statystychne modelyuvannya ta prohnozuvannya [Statistical modeling and forecasting]. Kyiv: Kyyivs'kyy natsional'nyy ekonomichnyy universytet.

Kaftan, O. N. (1975). Nekotoryye gidromorfologicheskiye osobennosti rek Ukrainskikh Karpat (na primere r. Bystritsa-Nadvornyanskaya) [Some hydrometeorological features of the rivers of the Ukrainian Carpathians (on the example of the Bystrytsia-Nadvirnianska River)]. Melioratsiya $i$ vodnoye khozyaystvo, 34, 82-92.

Kaftan, O. N. \& Korbutiak, V. M. (2001). Zalyshkovyy vplyv zakrytykh kar'yeriv na khid ruslovykh deformatsiy [The residual influence of closed quarries on the channel deformations]. Naukovo-tekhnichnyy zbirnyk Avtomobil'ni dorohy i dorozhnye budivnytstvo, 63, 170-172.

Khodnevych, Y. V., Stefanyshyn, D. V. \& Korbutiak, V. M. (2017). Imitatsiyne modelyuvannya umov vynyknennya mistsevykh rozmyviv rusel rik [Simulation of the conditions for the occurrence of local erosion of the river channels]. Ekolohichna bezpeka ta pryrodokorystuvannya, 24 (3-4), 112-123.

Korbutiak, V. M. (2000). Dynamika ruslovykh deformatsiy r. Bystrytsya Nadvirnyans'ka [Dynamic of river bed deformations of Bystrytsia Nadvirnianska River]. Hidromelioratsiya ta hidrotekhnichne budivnytstvo: zbirnyk naukovykh prats', 25, 27-33.

Korbutiak, V. M., Korbutiak, M. V. \& Kaftan, O. N. (2013). Vykorystannya danykh hidromorfolohichnykh obstezhen' rusel richok Ukrayins'kykh Karpat dlya rozrakhunku zlyvovykh pavodkiv [Using data of hydromorphological surveys of the Ukrainian Carpathians rivers for the calculation of rainfall floods]. Ekolohichna bezpeka ta pryrodokorystuvannya, 12, 89-97.

Koutsoyiannis, D. (2008). Probability and statistics for geophysical processes. Athens: National Technical University of Athens.

Kritskyi, S. N. \& Menkel', M. F. (1981). Gidrologicheskiye osnovy upravleniya rechnym stokom [The hydrological basis of management of river runoff]. Moskva: Nauka.

Kyryliuk, M. I. (2001). Rezhym formuvannya istorychnykh pavodkiv v Ukrayins'kykh Karpatakh [The regime of for- 
Korbutiak, V., Stefanyshyn, D., Lahodniuk, O., Lahodniuk, A. (2020). The combined approach to solving issues of the flood hazard assessment using water gauge records and spatial data. Acta Sci. Pol. Architectura, 19 (1), 111-118. doi: 10.22630/ASPA.2020.19.1.12

mation of historical floods in the Ukrainian Carpathians]. Hidrolohiya, hidrokhimiya i hidroekolohiya - Hydrology, Hydrochemistry and Hydroecology, 2, 163-167.

Raven, P. H. \& Berg, L. R. (2006). Environment. 5th ed. Hoboken, NJ: John Wiley \& Sons.

Rozhdestvenskyi, A. V., Ezhov, A. V. \& Sakhariuk, A. V. (1990). Otsenka tochnosti gidrologicheskikh raschetov [Assessment of the accuracy of hydrological calculations]. Leningrad: Gidrometeoizdat.

Rufat, S., Tate, E., Burton Ch., G. \& Say, M. A. (2015). Social vulnerability to floods: review of case studies and implications for measurement. International Journal of Disaster Risk Reduction, 14 (4), 470-486.

Stefanyshyn, D. V. (2011). Prohnozuvannya avariy na hreblyakh v zadachakh otsinky y zabezpechennya yikh nadiynosti ta bezpeky [Forecasting of accidents on the dam in the tasks of assessment and ensuring their reliability and safety]. Hidroenerhetyka Ukrayiny, 3-4, 52-60.

Stefanyshyn, D. V. (2015). Obgruntuvannya ekonomichno optymal'noho znachennya rozrakhunkovoyi vytraty vody maloyi ymovirnosti perevyshchennya na vodopropusknykh sporudakh z vrakhuvannyam ryzyku [The rationale for cost-optimal values of the design water flow rate low probability of exceedance for culvert structures risk-based]. Matematychne modelyuvannya $v$ ekonomitsi, 2, 104-111.

Stefanyshyn, D. V., Korbutiak, V. M. \& Schodro, O. E. (2010). Analiz khodu ruslovoho protsesu peredhirs'kykh dilyanok karpats'kykh richok z metoyu vyyavlennya nebezpechnykh dilyanok [Analysis of the tendentious of the channel process in submountain areas of the Carpathian Rivers for identifying insecure sections]. Visnyk Natsional'noho universytetu vodnoho hospodarstva ta pryrodokorystuvannya. Tekhnichni nauky, 51 (3), 80-86.

Stefanyshyna-Havryliuk, Y. D., Stefanyshyn, D. V. \& Trofimchuk, O. M. (2014). Induktyvne modelyuvannya ryzykiv zbytkiv vidruynivnykh poveney $\mathrm{v}$ baseyni $\mathrm{r}$. Tysa za empirychnymy danymyz vykorystannyam modeley rehresiynoho typu [Inductive modeling the risks of losses of devastating floods in the basin of Tisza river on empirical data using the regression type model]. Matematychne modelyuvannya $v$ ekonomitsi, 1, 72-79.

Susidko, M. M. (2006). Nadzvychayno vysoki poveni v baseyni Pryp'yati [Extremely high floods in the Pripyat basin]. Naukovi praci UkrNDHMI, 255, 279-282.

Susidko, M. M. \& Lukianets', O. I. (2004). Rayonuvannya terytoriyi Ukrayiny za stupenem hidrolohichnoyi nebezpeky [Zoning of the territory of Ukraine by the level of hydrological danger]. Naukovi praci UkrNDHMI, 253, 196-204.

Tikhonov, A. N., Honcharskyi, A. V., Stepanov, V. V. \& Yagola, A. H. (1983). Regulyariziruyushchiye algoritmy i apriornaya informatsiya [Regularizing algorithms and a priori information]. Moskva: Nauka.

Viessman, J. W., Harbaugh, T. E. \& Knapp, J. W. (1975). Introduction to hydrology. 2nd ed. New York - London: Intext Educational Publishers.

\section{ŁĄCZONE PODEJŚCIE DO ROZWIACZYWANIA ZAGADNIEŃ OCENY ZAGROŻEŃ POWODZIOWYCH Z WYKORZYSTANIEM DANYCH WODOWSKAZOWYCH I DANYCH PRZESTRZENNYCH}

\section{STRESZCZENIE}

Badanie dotyczy połączonego podejścia do zwiększenia wiarygodności szacunków hydrologicznych na podstawie serii danych hydrologicznych z wykorzystaniem danych przestrzennych. W szczególności rozważa się zastosowanie różnych teoretycznych krzywych rozkładu prawdopodobieństwa lub sytuacji, które mogą wystąpić na podgórskich odcinkach rzek (na przykład akumulacja aluwialna lub erozja koryta rzeki). Ze względu na nieaktualne dane katastralne dotyczące koryt i zlewni uzasadniona jest konieczność zastosowania teledetekcji. Dynamika zmian profili przekroju rzeki pozwala ocenić kierunek deformacji kanału - pogłębiania i prostowania kanałów rzeki lub zwiększania ich wymiarów poprzecznych. Informacje te mogą uzupełnić ocenę ochrony przeciwpowodziowej terytoriów.

Słowa kluczowe: przepływy wody, przekształcenia koryt rzek, wpływ antropogeniczny, dane hydrologiczne 